Т. В. Опрошанська ${ }^{1}$ О. П. Хворост ${ }^{1}$, В. В. Кудря ${ }^{2}$

НАЦІОНАЛЬНИЙ ФАРМАЦЕВТИЧНИЙ УНІВЕРСИТЕТ', ХАРКІВ ВІННИЦЬКИЙ НАЦІОНАЛЬНИЙ МЕДИЧНИЙ УНІВЕРСИТЕТ ІМ. М. І. ПИРОГОВА

\title{
КІЛЬКІСНИЙ ВМІСТ СУМИ ОРГАНІЧНИХ КИСЛОТ У СЕРІЯХ СИРОВИНИ ДЕЯКИХ ПРЕДСТАВНИКІВ РОДИН РОLYGONACEAE, ROSACEAE ТА ASTERACEAE
}

Вступ. Зважаючи на фрізіологічну активність органічних кислот в організмі людини, пошук нових рослинних джерел цієї групи біологічно активних речовин $є$ актуальним.

Мета дослідження - визначити кількісний вміст суми органічних кислот у кореневищах з коренями щавлю кінського, кореневищах з коренями родовика лікарського, коренях шипшини коричної, коренях шипшини собачої, коренях лопуха малого, коренях лопуха павутинистого і траві череди трироздільної за методиками монографрій ДФУ 2.0.

Методи дослідження. Кількісний вміст суми органічних кислот визначали за методиками монографрій ДФУ 2.0 “Шипшини плоди" (в перерахунку на яблучну кислоту) та "Калини плоди" (в перерахунку на лимонну кислоту).

Результати й обговорення. При використанні методики монографії “Шипшини плоди” було одержано дещо вищі результати визначення кількісного вмісту суми органічних кислот у сировині, яку вивчали, ніж дані, отримані при застосуванні методики монографрії “Калини плоди”. Це, найімовірніше, пов'язано 3 пробопідготовкою та гістологічними особливостями підземних органів, до складу яких входить значний відсоток здерев'янілих тканин. Водночас результати кількісного визначення чієї групи сполук у серіях трави череди трироздільної за двома методиками були зіставними. Кількісний вміст суми органічних кислот у різних серіях одного виду сировини в рамках використання кожної методики коливався незначно.

Висновки. Уперше визначено кількісний вміст суми органічних кислот у кореневищах з коренями щавлю кінського, кореневищах з коренями родовика лікарського, коренях шипшини коричної, коренях шипшини собачої, коренях лопуха малого, коренях лопуха павутинистого і траві череди трироздільної з використанням методик монографрій ДФУ 2.0. Встановлено, що вміст суми органічних кислот у всіх об'єктах, які досліджували, більший при застосуванні методики монографії “Шипшини плоди”, в підземних органах родовика лікарського та щавлю кінського він був найвищий і становив не менше 3,7 та 3,5 \% відповідно. Отримані результати буде використано в подальших дослідженнях.

КЛЮЧОВІ СЛОВА: органічні кислоти; щавель; родовик; шипшина; лопух; череда.

ВСТУП. Така група БАР, як органічні кислоти, відіграє важливу роль в організмі людини, оскільки ці сполуки беруть участь в обміні речовин, активізують роботу слинних залоз, стимулюють роботу шлунково-кишкового тракту та проявляють бактерицидну, антимікробну, протизапальну активність [1-4]. Традиційно склалося так, що основним джерелом органічних кислот (їх ще називають харчовими) вважають ягоди та фррукти, які містять в основному лимонну, яблучну, щавлеву, винну, янтарну кислоти [5]. Останнім часом усе більше уваги приділяють різним видам рослинної сировини, яка у своєму складі, поряд 3 головними діючими речовинами (наприклад, фенольними сполуками, леткими речовинами тощо), містить і органічні кислоти. У цьому ас(с) Т. В. Опрошанська, О. П. Хворост, В. В. Кудря, 2020. пекті нашу увагу привернула сировина розповсюджених в Україні представників родин Polygonaceae (щавель кінський - Rumex confertus Willd.), Rosaceae (родовик лікарський - Sanguisorba officinalis L., шипшина корична - Rosa majalis Herrm., шипшина собача - Rosa canina L.) та Asteraceae (лопух малий-Arctium minus (Hill) Bernh., лопух павутинистий - Arctium tomentosum Mill., череда трироздільна - Bidens tripartita L.), що містить органічні кислоти $[6,7]$.

3 літературних джерел відомо, що надземні органи щавлю кінського містять велику кількість щавлевої кислоти, надмірний вміст якої в організмі людини призводить до утворення оксалатних каменів, але відомості щодо кількісного вмісту цієї сполуки в підземних органах суперечливі [8]. 
Раніше ми встановили кількісний вміст суми органічних кислот у сировині деяких представників родин Asteraceae та Rosaceae за методикою статті № 38 "Плоди шипшини" Державної срармакопеї СРСР XI видання в перерахунку на яблучну кислоту [9]. Вміст даної групи сполук у

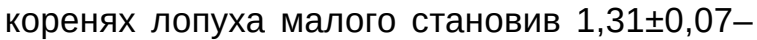
$1,58 \pm 0,08 \%$, коренях лопуха павутинистого $1,31 \pm 0,07-1,57 \pm 0,08 \%$, коренях шипшини коричної - 3,38 $\pm 0,23-5,07 \pm 0,31 \%$, коренях шипшини собачої - 3,29 $\pm 0,22-4,54 \pm 0,28 \%[10,11]$. Крім того, $€$ відомості про кількісний вміст цієї групи речовин у кореневищах 3 коренями родовика лікарського (визначали за методикою статті № 38 “Плоди шипшини" Державної фрармакопеї СРСР XI видання), що коливався від $(2,55 \pm 0,10)$ до $(3,00 \pm 0,12) \%$ залежно від місця заготівлі сировини $[9,12]$. Трава череди трироздільної також містить органічні кислоти [6].

Отже, встановлення кількісного вмісту суми органічних кислот у сировині поширених рослин родин Polygonaceae, Rosaceae та Asteraceae 3 використанням методик, які наведено у монографріях Державної Фармакопеї України II видання (ДФУ 2.0), є актуальним.

Мета дослідження - визначити кількісний вміст суми органічних кислот у кореневищах 3 коренями щавлю кінського, кореневищах з коренями родовика лікарського, коренях шипшини коричної, коренях шипшини собачої, коренях лопуха малого, коренях лопуха павутинистого і траві череди трироздільної за методиками монографрій ДФУ 2.0.

МЕТОДИ ДОСЛІДЖЕННЯ. ЯК Об'єкТИ ДОслідження використовували кореневища з коренями щавлю кінського, кореневища 3 коренями родовика лікарського, корені шипшини коричної, корені шипшини собачої, корені лопуха малого, корені лопуха павутинистого і траву череди трироздільної (по 7 серій кожного виду ЛРС). Підземні органи заготовлювали наприкінці вегетаційного періоду, а траву - у фазу бутонізації у 2019 р. у різних областях України. Кількісний вміст органічних кислот визначали за методиками, які наведено у монографріях ДФУ 2.0 - "Шипшини плоди" (в перерахунку на яблучну кислоту) [13] та "Калини плоди" (в перерахунку на лимонну кислоту) [14].

РЕЗУЛЬТАТИЙ ОБГОВОРЕННЯ. РеЗУЛЬТаТИ дослідження наведено в таблиці.

Як видно з таблиці, при використанні методики монографрії "Шипшини плоди" було одер-

Таблиця - Кількісний вміст суми органічних кислот у сировині рослин родин Polygonaceae, Rosaceae та Asteraceae

\begin{tabular}{|c|c|c|c|}
\hline \multirow[b]{2}{*}{ Назва сировини } & \multirow[b]{2}{*}{ Серія } & \multicolumn{2}{|c|}{ Кількісний вміст суми органічних кислот за методикою } \\
\hline & & $\begin{array}{c}\text { монограсрії “Шипшини плоди" } \\
\text { (в перерахунку на яблучну кислоту) }\end{array}$ & $\begin{array}{c}\text { монографрії “Калини плоди" } \\
\text { (в перерахунку на лимонну кислоту) }\end{array}$ \\
\hline \multirow{7}{*}{$\begin{array}{l}\text { Кореневища } \\
3 \text { коренями } \\
\text { щавлю кінського }\end{array}$} & 1.1 & $3,63 \pm 0,12$ & $2,20 \pm 0,07$ \\
\hline & 1.2 & $3,62 \pm 0,14$ & $2,21 \pm 0,08$ \\
\hline & 1.3 & $3,59 \pm 0,11$ & $2,12 \pm 0,07$ \\
\hline & 1.4 & $3,56 \pm 0,13$ & $2,15 \pm 0,07$ \\
\hline & 1.5 & $3,60 \pm 0,12$ & $2,14 \pm 0,07$ \\
\hline & 1.6 & $3,55 \pm 0,12$ & $2,12 \pm 0,07$ \\
\hline & 1.7 & $3,55 \pm 0,11$ & $2,13 \pm 0,07$ \\
\hline \multirow{7}{*}{$\begin{array}{l}\text { Кореневища } \\
\text { з коренями } \\
\text { родовика } \\
\text { лікарського }\end{array}$} & 2.1 & $3,78 \pm 0,12$ & $1,84 \pm 0,06$ \\
\hline & 2.2 & $3,72 \pm 0,12$ & $1,87 \pm 0,06$ \\
\hline & 2.3 & $3,71 \pm 0,12$ & $1,85 \pm 0,06$ \\
\hline & 2.4 & $3,81 \pm 0,12$ & $1,84 \pm 0,06$ \\
\hline & 2.5 & $3,75 \pm 0,12$ & $1,83 \pm 0,06$ \\
\hline & 2.6 & $3,71 \pm 0,11$ & $1,84 \pm 0,06$ \\
\hline & 2.7 & $3,75 \pm 0,12$ & $1,85 \pm 0,06$ \\
\hline \multirow{7}{*}{$\begin{array}{l}\text { Корені шипшини } \\
\text { коричної }\end{array}$} & 3.1 & $1,69 \pm 0,06$ & $0,86 \pm 0,03$ \\
\hline & 3.2 & $1,69 \pm 0,05$ & $0,86 \pm 0,03$ \\
\hline & 3.3 & $1,69 \pm 0,05$ & $0,87 \pm 0,03$ \\
\hline & 3.4 & $1,69 \pm 0,05$ & $0,86 \pm 0,03$ \\
\hline & 3.5 & $1,68 \pm 0,06$ & $0,86 \pm 0,03$ \\
\hline & 3.6 & $1,69 \pm 0,05$ & $0,87 \pm 0,03$ \\
\hline & 3.7 & $1,69 \pm 0,06$ & $0,86 \pm 0,03$ \\
\hline \multirow{7}{*}{$\begin{array}{l}\text { Корені шипшини } \\
\text { собачої }\end{array}$} & 4.1 & $1,41 \pm 0,04$ & $0,86 \pm 0,03$ \\
\hline & 4.2 & $1,41 \pm 0,05$ & $0,86 \pm 0,03$ \\
\hline & 4.3 & $1,39 \pm 0,05$ & $0,85 \pm 0,03$ \\
\hline & 4.4 & $1,39 \pm 0,05$ & $0,85 \pm 0,03$ \\
\hline & 4.5 & $1,40 \pm 0,04$ & $0,85 \pm 0,03$ \\
\hline & 4.6 & $1,39 \pm 0,04$ & $0,85 \pm 0,03$ \\
\hline & 4.7 & $1,40 \pm 0,05$ & $0,85 \pm 0,03$ \\
\hline
\end{tabular}


Продовження табл.

\begin{tabular}{|c|c|c|c|}
\hline \multirow[b]{2}{*}{ Назва сировини } & \multirow[b]{2}{*}{ Серія } & \multicolumn{2}{|c|}{ Кількісний вміст суми органічних кислот, \% за методикою } \\
\hline & & $\begin{array}{c}\text { монограсрії “Шипшини плоди” } \\
\text { (в перерахунку на яблучну кислоту) }\end{array}$ & $\begin{array}{c}\text { монографрії “Калини плоди” } \\
\text { (в перерахунку на лимонну кислоту) }\end{array}$ \\
\hline \multirow{7}{*}{$\begin{array}{l}\text { Корені лопуха } \\
\text { малого }\end{array}$} & 6.1 & $1,95 \pm 0,06$ & $1,51 \pm 0,05$ \\
\hline & 6.2 & $2,00 \pm 0,07$ & $1,51 \pm 0,05$ \\
\hline & 6.3 & $2,01 \pm 0,07$ & $1,51 \pm 0,05$ \\
\hline & 6.4 & $1,99 \pm 0,06$ & $1,51 \pm 0,05$ \\
\hline & 6.5 & $1,97 \pm 0,07$ & $1,50 \pm 0,05$ \\
\hline & 6.6 & $1,97 \pm 0,06$ & $1,50 \pm 0,05$ \\
\hline & 6.7 & $1,98 \pm 0,06$ & $1,49 \pm 0,06$ \\
\hline \multirow{7}{*}{$\begin{array}{l}\text { Корені лопуха } \\
\text { павутинистого }\end{array}$} & 7.1 & $2,02 \pm 0,06$ & $1,25 \pm 0,05$ \\
\hline & 7.2 & $2,03 \pm 0,06$ & $1,26 \pm 0,04$ \\
\hline & 7.3 & $2,02 \pm 0,06$ & $1,27 \pm 0,04$ \\
\hline & 7.4 & $2,02 \pm 0,07$ & $1,28 \pm 0,04$ \\
\hline & 7.5 & $2,03 \pm 0,07$ & $1,29 \pm 0,04$ \\
\hline & 7.6 & $2,03 \pm 0,07$ & $1,29 \pm 0,04$ \\
\hline & 7.7 & $2,03 \pm 0,07$ & $1,28 \pm 0,04$ \\
\hline \multirow{7}{*}{$\begin{array}{l}\text { Трава череди } \\
\text { трироздільної }\end{array}$} & 8.1 & $1,24 \pm 0,04$ & $1,24 \pm 0,04$ \\
\hline & 8.2 & $1,24 \pm 0,04$ & $1,22 \pm 0,04$ \\
\hline & 8.3 & $1,23 \pm 0,04$ & $1,22 \pm 0,04$ \\
\hline & 8.4 & $1,23 \pm 0,04$ & $1,23 \pm 0,04$ \\
\hline & 8.5 & $1,23 \pm 0,04$ & $1,23 \pm 0,04$ \\
\hline & 8.6 & $1,24 \pm 0,04$ & $1,23 \pm 0,04$ \\
\hline & 8.7 & $1,24 \pm 0,04$ & $1,22 \pm 0,04$ \\
\hline
\end{tabular}

жано дещо вищі результати кількісного вмісту суми органічних кислот у сировині, яку вивчали, ніж дані, отримані при застосуванні методики монографрії "Калини плоди". Це, найімовірніше, пов'язано з різними підходами до пробопідготовки та гістологічними особливостями підземних органів, до складу яких входить значний відсоток здерев'янілих тканин. Водночас результати кількісного визначення цієї групи сполук у такому виді сировини, як трава (в серіях трави череди трироздільної), за двома методиками були зіставними.

Кількісний вміст суми органічних кислот у різних серіях одного виду сировини в рамках використання кожної методики коливався незначно. Найвищий вміст суми органічних кислот було визначено в підземних органах родовика лікарського та щавлю кінського - $(3,81 \pm 0,12)$ i $(3,63 \pm 0,12)$ \% відповідно (за методикою монографіії "Шипшини плоди").
ВИСНОВКИ. Уперше проведено визначення кількісного вмісту суми органічних кислот у 7 серіях кореневищ 3 коренями щавлю кінського, кореневищ 3 коренями родовика лікарського, коренів шипшини коричної, коренів шипшини собачої, коренів лопуха малого, коренів лопуха павутинистого і трави череди трироздільної 3 використанням методик монографій ДФУ 2.0 “Шипшини плоди" та "Калини плоди”.

Встановлено, що вміст суми органічних кислот у всіх об'єктах, які досліджували, більший при застосуванні методики монограсрії “Шипшини плоди", в підземних органах родовика лікарського та щавлю кінського він був найвищий і становив не менше 3,7 та 3,5 \% відповідно.

Отримані результати буде використано в подальших дослідженнях.

Конфлікт інтересів. Автори підтверджують відсутність конфрлікту інтересів у цій публікації.

\section{СПИСОК ЛІТЕРАТУРИ}

1. Москаленко А. М. Дослідження органічних кислот сировини безсмертника приквіткового (Helichrysum bracteatum) / А. М. Москаленко, Н. В. Попова // Укр. біофрармац. журн. - 2019. - № 4. - С. 65-69.

2. Analysis of organic acids of tricarboxylic acid cycle in plants using GC-MS, and system modeling / Kumar
Vinod, Sharma Anket, Bhardwaj Renu, Kumar Thukral Ashwani // Journal of Analytical Science and Technology. 2017. - 8. - P. 20.

3. Сініченко А. В. Дослідження органічних кислот культивованих видів роду Primula L. / A. B. Сініченко, С. М. Марчишин // Інновації в медицині : матеріали 
87-ї наук.-практ. конфр. студентів та молодих вчених 3 міжнар. участю, 22-23 берез. 2018 р. - Івано-Франківськ, 2018. - С. 106-107.

4. Simultaneous determination of 14 organic acids in Shenfu injection by hydrophilic interaction chromatography-tandem mass spectrometry / Yao Liu, Na Zhang, ShePo Shi [et al.] // Zhongguo Zhong Yao Za Zhi. 2016. - 41 (18). - P. 3342-3348.

5. Optimization of conditions for organic acid extraction from edible plant material as applied to radish sprouts / Joanna Chlopicka, Justyna DobrowolskaIwanek, Michal Wozniakiewicz, Pawel Zagrodzki // Food Analytical Methods. - 2014. - 7 (6). - P.1323-1327.

6. Алексєєв І. Повний атлас лікарських рослин / І. Алексєєв, А. Діброва. - К. : Глорія, 2019. - 256 с.

7. Phytotherapeutic activities of Sanguisorba officinalis and its chemical constituents: A review / Eungyeong Jang, Kyung-Soo Inn, Young Pyo Jang [et al.] // The American Journal of Chinese Medicine. - 2018. 46 (02). - P. 1-20.

8. Зайцева Н. В. Фармакогностическое исследование и стандартизация корней щавеля конского (Rumex confertus WILLD.) : дисс. канд. фрармац. наук : 14.04.02 / Зайцева Надежда Вячеславовна. - Самара, 2014. - 140 c

9. Государственная фрармакопея СССР XI изд. Вып. 1. Общие методы анализа. - М. : Медицина, 1987. - 334 c.

\section{REFERENCES}

1. Moskalenko, A.M. \& Popova, N.V. (2019). Doslidzhennia orhanichnykh kyslot syrovyny bezsmertnyka prykvitkovoho (Helichrysum bracteatum) [Research of organic acids of raw immortelle bracts (Helichrysum bracteatum)]. Ukrainskyi biofarmatsevtychnyi zhurnal Ukrainian Biopharmaceutical Journal, 4, 65-69 [in Ukrainian].

2. Kumar Vinod, Sharma Anket, Bhardwaj Renu \& Kumar Thukral Ashwani (2017). Analysis of organic acids of tricarboxylic acid cycle in plants using GC-MS, and system modeling. Journal of Analytical Science and Technology, 8, 20.

3. Sinichenko, A.V., \& Marchyshyn, S.M. (2018). Doslidzhennia orhanichnykh kyslot kultyvovanykh vydiv rodu Primula L. [Research of organic acids of cultivated species of the genus Primula L.]. Abstracts of papers $87-i$ naukovo-prakt. konf. studentiv ta molodykh vchenykh z mizhnarodnoiu uchastiu "Innovatsii v medytsyni" Proceeding of the 87th Scientific Practice. Conf. of Students and Young Scientists with International Participation "Innovations in Medicine". Ivano-Frankivsk. [in Ukrainian].

4. Yao Liu, Na Zhang, ShePo Shi Qingqing Song, Jielan Li, Yuelin Song \& Peng-Fei Tu. (2018). Simultaneous determination of 14 organic acids in Shenfu injection by hydrophilic interaction chromatography-tandem mass spectrometry. Zhongguo Zhong Yao Za Zhi, 41 (18), 3342-3348.

5. Joanna Chlopicka, Justyna Dobrowolska-Iwanek, Michal Wozniakiewicz \& Pawel Zagrodzki. (2014). Opti-
10. Oproshanska T. V. Quantitative content of organic acids and ascorbic acid in the root of plants genus of Arctium / T. V. Oproshanska, O. P. Khvorost // Зб. наукових праць співробітників НМАПО ім. П. Л. Шупика 2017. - Вип. 28. - С. 87-93.

11. Oproshanska T. V. Determination of quantitative content of amount of organic acids and ascorbic acid in different series of Rosa majalis and Rosa canina raw materials / T. V. Oproshanska, O. P. Khvorost, L. V. Ocheredko // Visnik of Pharmacy. - 2017. - No. 1. - P. 10-13.

12. Marchyshyn S. Investigation of organic acids of Sanguisorba officinalis rhizomes with roots and herb (Sanguisorba officinalis L.) / S. Marchyshyn, V. Kudrja, S. Nakonechna // The Pharma Innovation Journal. 2018. - No. 7 (6). P. 216-218.

13. Державна Фармакопея України / Державне підприємство "Український науковий фрармакопейний центр якості лікарських засобів". - 2-ге вид. - Доповнення 1. - Харків : Державне підприємство "Український науковий фрармакопейний центр якості лікарських засобів", 2016. - 360 с.

14. Державна Фармакопея України / Державне підприємство "Український науковий фрармакопейний центр якості лікарських засобів". - 2-ге вид. - Доповнення 4. - Харків : Державне підприємство "Український науковий фрармакопейний центр якості лікарських засобів", 2020. - 600 с. mization of conditions for organic acid extraction from edible plant material as applied to radish sprouts. Food Analytical Methods, 7 (6), 1323-1327.

6. Aleksyeyev, I., \& Dibrova. A. (2019). Povnyi atlas likarskykh roslyn [Complete atlas of medicinal plants]. [in Ukrainian].

7. Eungyeong Jang, Kyung-Soo Inn, Young Pyo Jang, Kyung-Tae Lee \& Jang-Hoon Lee. (2018). Phytotherapeutic activities of Sanguisorba officinalis and its chemical constituents: A review. The American Journal of Chinese Medicine, 46 (02), 1-20.

8. Zajczeva, N.V. (2014). Gosudarstvennoye byudzhetnoye obrazovatelnoe uchrezhdenie vysshego professionalnogo obrazovaniya [Pharmacognostic study and standardization of the roots of horse sorrel (Rumex confertus WILLD)]. Candidate's thesis. Samara State Medical University, Samara [in Russian].

9. (1987). Gosudarstvennaya farmakopeya SSSR $X I$ izd. Vyp. 1. Obshchie metody analiza [State Pharmacopoeia of the USSR XI ed. Issue 1. General methods of analysis]. Moscow: Meditsina [in Russian].

10. Oproshanska, T.V., \& Khvorost, O.P. (2017). Quantitative content of organic acids and ascorbic acid in the root of plants genus of Arctium. $Z b$. naukovykh prats spivrobitnykiv NMAPO im. P. L. Shupyka - Collection of Scientific Works of Employees of NMAPO by P. L. Shupyk, 28, 87-93.

11. Oproshanska, T.V., Khvorost, O.P., \& Ocheredko, L.V. (2017). Determination of quantitative content of 
amount of organic acids and ascorbic acid in different series of Rosa majalis and Rosa canina raw materials. Visnik of Pharmacy, 1, 10-13.

12. Marchyshyn, S., Kudrja, V., \& Nakonechna, S. (2018). Investigation of organic acids of Sanguisorba officinalis rhizomes with roots and herb (Sanguisorba officinalis L.). The Pharma Innovation Journal, 7 (6), 216-218.

13. (2016). Derzhavna Farmakopeia Ukrainy. 2-e vyd. Dopovnennia 1. [State Pharmacopoeia of Ukraine. $2^{\text {nd }}$ edition. Appendix 1.]. Kharkiv: Derzhavne pidpryiemstvo "Ukrainskyi naukovyi farmakopejnyi tsentr yakosti likarskykh zasobiv" [in Ukrainian].

14. (2020). Derzhavna Farmakopeia Ukrainy. 2-e vyd. Dopovnennia 4. [State Pharmacopoeia of Ukraine. $2^{\text {nd }}$ edition. Appendix 41.]. Kharkiv: Derzhavne pidpryiemstvo "Ukrainskyi naukovyi farmakopejnyi tsentr yakosti likarskykh zasobiv" [in Ukrainian].

\section{Т. В. Опрошанская ${ }^{1}$, О. П. Хворост ${ }^{1}$, В. В. Кудря ${ }^{2}$ НАЦИОНАЛЬНЫЙ ФАРМАЦЕВТИЧЕСКИЙ УНИВЕРСИТЕТ ${ }^{1}$, ХАРЬКОВ ВИННИЦКИЙ НАЦИОНАЛЬНЫЙ МЕДИЦИНСКИЙ УНИВЕРСИТЕТ ИМ. Н. И. ПИРОГОВА}

\section{КОЛИЧЕСТВЕННОЕ СОДЕРЖАНИЕ СУММЫ ОРГАНИЧЕСКИХ КИСЛОТ В СЕРИЯХ СЫРЬЯ НЕКОТОРЫХ ПРЕДСТАВИТЕЛЕЙ СЕМЕЙСТВ РОLYGONАСЕАЕ, ROSACEAE И ASTERACEAE}

\section{Резюме}

Вступление. Учитывая физиологическую активность органических кислот в организме человека, поиск новых растительных источников этой группы биологически активных веществ является актуальным.

Цель исследования - определить количественное содержание суммы органических кислот в корневищах с корнями щавеля конского, корневищах с корнями кровохлебки лекарственной, корнях шиповника коричного, корнях шиповника собачьего, корнях лопуха малого, корнях лопуха паутинистого и траве череды трехраздельной по методикам монографрий ГФУ 2.0.

Методы исследования. Количественное содержание суммы органических кислот определяли по методикам монографий ГФУ 2.0 "Шиповника плоды" (в пересчете на яблочную кислоту) и "Калины плоды" (в пересчете на лимонную кислоту).

Результаты и обсуждение. При использовании методики монографии “Шиповника плоды" было получено более высокие результаты определения количественного содержания суммы органических кислот в сырье, которое изучали, чем данные, полученные при применении методики монографрии "Калины плоды". Это, скорее всего, связано с пробоподготовкой и гистологическими особенностями подземных органов, в состав которых входит значительный процент одревесневших тканей. В то же время результаты количественного определения этой группы соединений в сериях травы череды трехраздельной по двум методикам были сопоставимы. Количественное содержание суммы органических кислот в различных сериях одного вида сырья в рамках использования каждой методики колебалось незначительно.

Выводы. Впервые определено количественное содержание суммы органических кислот в корневищах с корнями щавеля конского, корневищах с корнями кровохлебки лекарственной, корнях шиповника коричного, корнях шиповника собачьего, корнях лопуха малого, корнях лопуха паутинистого и траве череды трехраздельной с использованием методик монографиий ГФУ 2.0. Установлено, что содержание суммы органических кислот во всех объектах, которые исследовали, больше при применении методики монографрии “Шиповника плоды”, в подземных органах кровохлебки лекарственной и щавеля конского оно было самое высокое и составило не менее 3,7 и 3,5 \% соответственно. Полученные результаты будут использованы в дальнейших исследованиях.

КЛЮЧЕВЫЕ СЛОВА: органические кислоты; щавель; кровохлебка; шиповник; лопух; череда. 
T. V. Oproshanska ${ }^{1}$, O. P. Khvorost ${ }^{1}$, V. V. Kudria ${ }^{2}$ NATIONAL UNIVERSITY OF PHARMACY' ${ }^{1}$ KHARKIV

M. PYROHOV VINNYTSIA NATIONAL MEDICAL UNIVERSITY

\title{
QUANTITATIVE CONTENT OF THE AMOUNT OF ORGANIC ACIDS IN THE SERIES OF RAW MATERIALS OF SOME SPECIES OF THE FAMILIES POLYGONACEAE, ROSACEAE AND ASTERACEAE
}

\begin{abstract}
Summary
Introduction. Considering to the physiological activity of organic acids for the human body, the search of new sources of this group of biologically active substances is urgent.

The aim of the study - to determine the quantitative content of organic acids in rhizomes with roots of Rumex confertus, rhizomes with roots of Sanguisorba officinalis, roots of Rosa majalis, roots of Rosa canina, roots of Arctium minus, roots of Arctium tomentosum, herbs of Bidens tripartita.

Research Methods. The quantitative content of organic acids amount was determined according to the methods given in the monographs of SPhU 2.0 - "Rose hips", in terms of malic acid and "Viburnum fruits", in terms of citric acid.

Results and Discussion. Using of the method from the monograph of "Rose hips" led to slightly higher results of determination in the quantitative content of the amount of organic acids in the studied raw materials than the method of the monograph "Viburnum fruits". It can be connected with the sample preparation and histological features of the underground organs, which include a significant percentage of woody tissues. At that time, the results of quantitative determination of this group of compounds in series of herbs of Bidens tripartita by two methods was comparable. The quantitative content of the sum of organic acids in different batches of one type of raw material within the use of each technique varied slightly.

Conclusions. For the first time it was carried out a quantitative content of the amount of organic acids in the rhizomes with roots of Rumex confertus, rhizomes with roots of Sanguisorba officinalis, roots of Rosa majalis, roots of Rosa canina, roots of Arctium minus, roots of Arctium tomentosum, herbs of Bidens tripartite with using methodics from the monographs of SPhU 2.0. It was found that the content of the total organic acids in all the objects that were studied was observed when using the method of the monograph "Rose hips", which was the highest in the underground organs of Sanguisorba officinalis and Rumex confertus and amounted to $3.7 \%$ and $3.5 \%$, respectively. The obtained results will be used in further research.
\end{abstract}

KEY WORDS: organic acids; rumex; sanguisorba; rosa; arctium; bidens.

Отримано 17.08.20

Адреса для листування: Т. В. Опрошанська, вул. Гв. Широнінців, 39б, кв. 124, Харків, 61170, Україна, e-mail: arctium55@ukr.net. 